\title{
Thermal Load Reduction with Green Building Envelope
}

\author{
Dilawar Husain*, Sarvesh Shukla, Vivek Kumar Umrao, Ravi Prakash \\ Department of Mechanical Engineering, Motilal Nehru National Institute of Technology, Allahabad, India \\ Email: *dilawar4friend@gmail.com,rprakash234@gmail.com
}

How to cite this paper: Husain, D., Shukla, S., Umrao, V.K. and Prakash, R. (2017) Thermal Load Reduction with Green Building Envelope. Open Journal of Energy Efficiency, 6, 112-127. https://doi.org/10.4236/ojee.2017.63009

Received: August 18, 2017

Accepted: September 22, 2017

Published: September 25, 2017

Copyright $\odot 2017$ by authors and Scientific Research Publishing Inc. This work is licensed under the Creative Commons Attribution International License (CC BY 4.0).

http://creativecommons.org/licenses/by/4.0/ (c) (i) Open Access

\begin{abstract}
Various studies have confirmed that high thermal resistance in roof \& wall can reduce the heat transfer load of the buildings. In this study, experimental investigation of the effects of some sustainable features (such as green roof, reflective coated roof \& Fly ash brick (FAB) etc.) on the building has been conducted in the Indian context. For the purpose, two scaled building models i.e. Model I (conventional design) \& Model II (green design) have been examined with different design configurations. The sensible heat transfer (SHT) load of the building is reduced by $21 \%-29 \%$ through the use of FAB with cavity wall in place of Fired clay brick (FCB) wall. The load reduction increases to $26 \%-44 \%$ by using $\mathrm{FAB}$ cavity wall with reflective coating on the roof. This reduction further increases to $64 \%-68 \%$ with $\mathrm{FAB}$ cavity wall along with green roof. In this final scenario, the monthly electrical energy saving for airconditioning is approximately $5.1 \mathrm{kWh} / \mathrm{m}^{2}$ per unit envelope area, with associated reduction in GHG emissions up to $6.36 \mathrm{~kg} \mathrm{CO} \mathrm{CO}_{2 \mathrm{eq}} / \mathrm{m}^{2}$ per unit envelope area, assuming continuous operation of HVAC systems.
\end{abstract}

\section{Keywords}

Sensible Heat Transfer Load, GHG Emission, Green Roof, Reflective Roof, Fly-Ash Bricks

\section{Introduction}

At the United Nations Climate Change Conference in 2015 at Paris, 195 members agreed to mitigate the impact of $\mathrm{CO}_{2}$ emissions on global warming, with the goal to limit global temperature rise below $2^{\circ} \mathrm{C}$ [1]. Sustainable building design can play a critical role in this effort. Buildings not only use the natural resources (raw materials, water, land etc.) and energy but also produce the wastes and greenhouse gas (GHG) emissions [2]. Recent studies identified that buildings are 
responsible for $30 \%-40 \%$ of total world energy use and $40 \%-50 \%$ of world GHG emissions [3] [4]. Ramesh et al. [5] suggested that building operational phase demand is in the range of $80 \%-90 \%$ of the total life cycle energy of the buildings. In India, the life cycle energy of the buildings is in the range of 240 $380 \mathrm{kWh} / \mathrm{m}^{2}$-year depending on the climatic condition and building envelope [6].

In recent years, the concept of sustainable building design has emerged that mainly aims to use green building design, eco-friendly materials and reduce the resource usage as well as life cycle energy. American Society of Heating, Refrigerating and Air Conditioning Engineers (ASHRAE) Standard 55 defines thermal comfort as "that state of mind which expresses satisfaction with the thermal environment." It involves the well-being of the occupants in a particular environment for a particular climate about their capacity to adapt to thermal equilibrium, physiological, psychological and behavioural changes [7]. Various active and passive techniques are used in a building to improve thermal comfort as well as reduce operational energy such as alternative building materials, insulation in built-envelope, live wall \& green roof etc. Double skin facade is an architectural element that has recently gained recognition in modern office buildings as a solution for highly glazed facades to reduce the annual HVAC system loads [8]. In India, fired clay brick (FCB) are used in buildings because of lack of technologies and less concern about environmental pollution. FCB has a high thermal conductivity that requires much amount of primary energy to maintain thermal comfort conditions in the buildings. Fay ash brick (FAB) has lower thermal conductivities $(0.90-1.05 \mathrm{~W} / \mathrm{m}-\mathrm{K})$ compared with the fired clay brick (FCB) $(1.25-1.35 \mathrm{~W} / \mathrm{m} \mathrm{K})$ and simultaneously solves the problem of disposal of the waste product (ash) from thermal power plants [9] [10]. Building insulation significantly reduces operating energy for thermal comfort. Kumar \& Suman [11] experimentally investigated the inside temperature difference of $4.8^{\circ} \mathrm{C} \& 9^{\circ} \mathrm{C}$ (during winter \& summer respectively) between insulated (synthetic) envelope and conventional envelope in Delhi, India. Loose fill insulation material obtained from rye grain, rye pulp, and other additives can be useful when cavity walls in wooden constructions have to be insulated [12].

Building colour and reflective coatings play significant role in cooling of the building and various studies suggest that use of light reflective colour provides better thermal comfort and reduced indoor temperature of the built envelope [13] [14] [15]. Akbari [16] examined the albedo effect on HVAC energy consumption and suggested that high-reflectivity roof coating can reduce energy consumption in the range of $8.7 \%-27.5 \%$. Green roofs are considered to be an effective contributor to reduced indoor temperature of the building and the solution of several environmental problems that occurs due to current urbanization. The impact of green roofs on the inside built envelope air temperature is more significant in hot climates. The mean inside built envelope air temperature compared to conventional roof was reduced by $2.6^{\circ} \mathrm{C}, 2.0^{\circ} \mathrm{C}$, and $1.4^{\circ} \mathrm{C}$ for 
Athens, La Rochelle, and Stockholm cities, respectively [17].

This study represents the experimental evaluation of thermal behaviour of different sustainable building design techniques in the climatic condition of Allahabad, India. Two scaled building models were constructed for this purpose: Model I-conventional building design (consists of FCB wall \& RCC roof), Model II-Improved building design (consists of FAB with cavity wall \& RCC roof with reflective coating/green roof).

\section{Methodology}

The building models constructed for the experiment are based on the standard of National Building Code, 2016 [18]. These scaled models have been constructed at one-third dimensions for convenience. So the total floor area is one-ninth of the $9.5 \mathrm{~m}^{2}$ (standard value) and the height is one-third of $3.5 \mathrm{~m}$ (standard value). The descriptions of the models are given below:

1) Model I

Model I (Figure 1) consists of fired clay brick (FCB), which is generally used

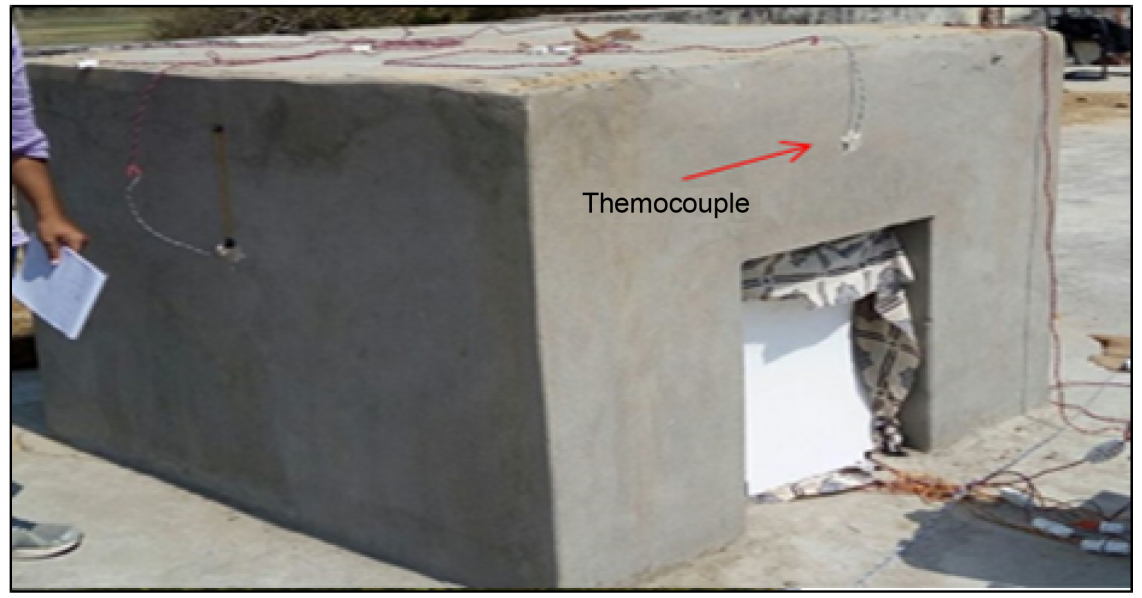

(a)

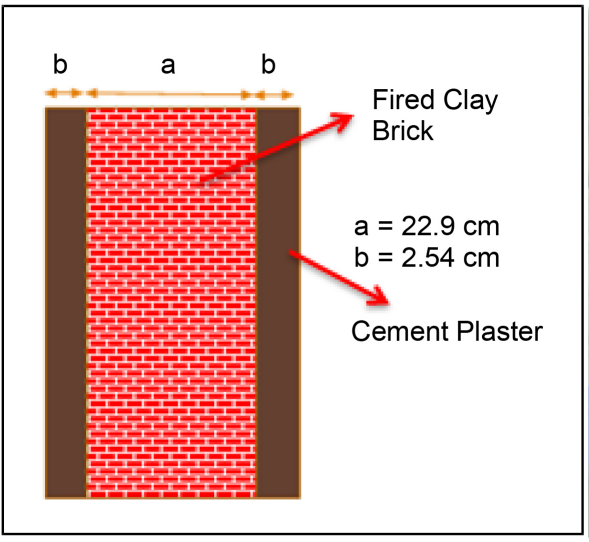

(b)

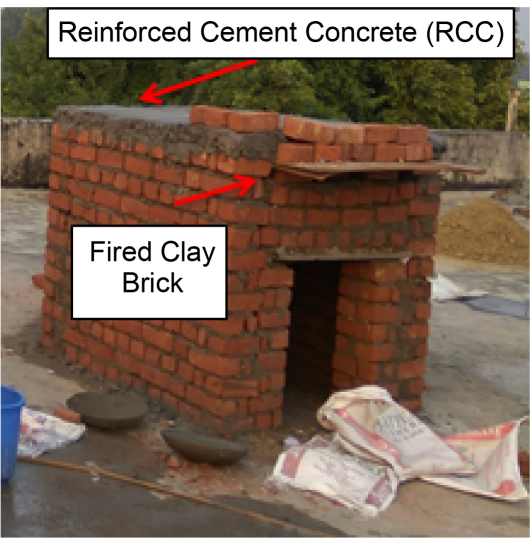

(c)

Figure 1. Image of Model I, (a) Image during experiment period; (b) Cross-section view of wall; (c) Image at the time of construction. 
as a building construction material in India. In this model, we have constructed the wall of 11 inches $(27.94 \mathrm{~cm})$ in thickness. The brickwork has 9 inches $(22.9$ $\mathrm{cm}$ ) in thickness and both sides of the wall have been plastered with a thickness of 1 inch $(2.54 \mathrm{~cm})$ of cement plaster. The opening of $30 \%$ area of south wall is made to take into account the combined effect of the window and door. The roof of the model is M20 concrete (2\% reinforced) of 4 inch $(10.16 \mathrm{~cm})$ thickness.

\section{2) Model II}

This model (Figure 2) is made of fly ash brick (FAB) as cavity wall. It reduces the environmental impact as compared to conventional building design because FAB made up of fly ash which is a waste product of thermal power plants. The thickness of outer and inner layer of the wall is 4 inch $(10.16 \mathrm{~cm})$ and there is cavity provided in between these two layers with the thickness of $5 \mathrm{~cm}$. As in Model I, in this model too we have made an opening in the south wall for the combined effect of the window and door.

The roof is made, in both cases, of M20 concrete ( $2 \%$ reinforced) with 4 inch $(10.16 \mathrm{~cm})$ thickness. In Model II, we have provided two air vents, one on the bottom of the north wall and another on top of the south wall. The dimension of air vent is $22.86 \mathrm{~cm} \times 6.35 \mathrm{~cm}$. The air vents are provided to replace the hot air on south wall with the cold air from north. As the cold air is heavy it will sink down so the north wall air vent opening is made on the bottom of the wall while

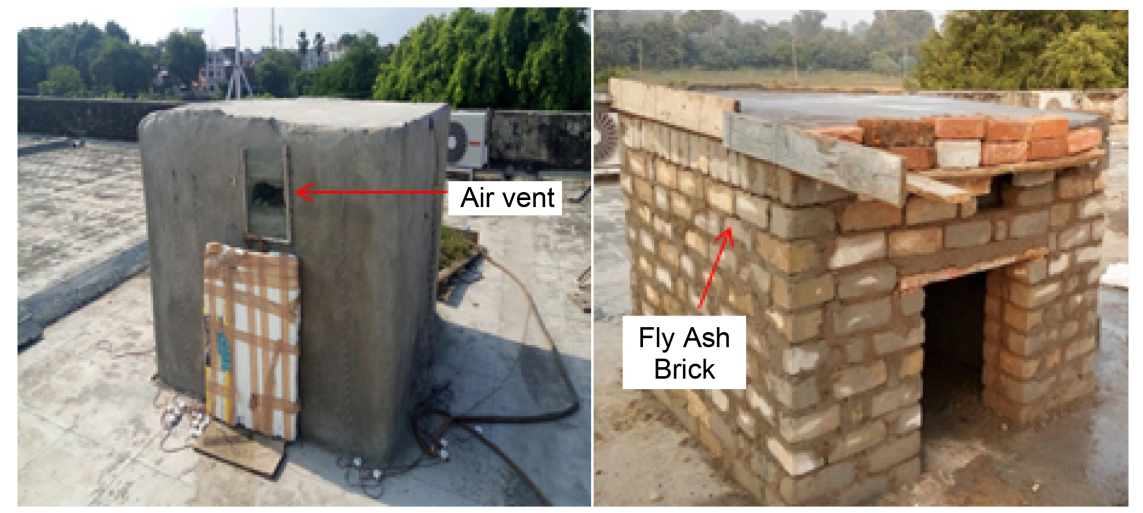

(a)

(b)

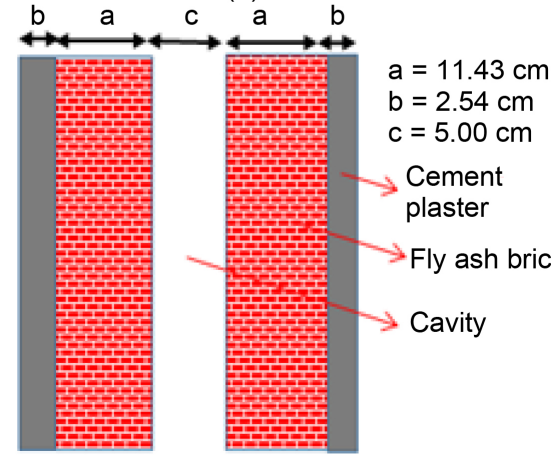

(c)

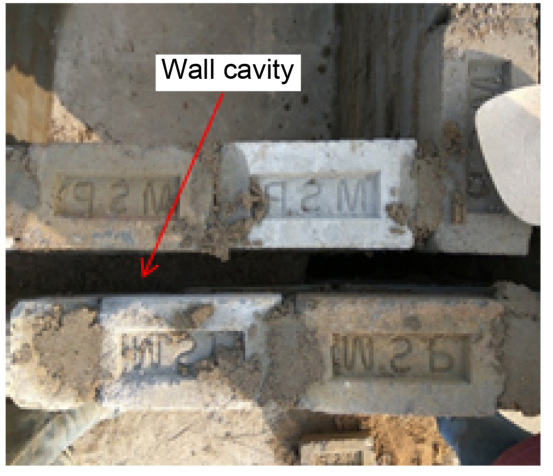

(d)

Figure 2. Image of Model II (a) Image during experiment time; (b) Image at the time of construction; (c) Cross-section view of wall; (d) Wall cavity $(5 \mathrm{~cm})$. 
the hot air rise up on the south wall due to direct heating so the vent is provided on the top of the wall. This will cause natural ventilation on the wall cavity, which will further cool the inner layer of the wall and maintain nearly uniform temperature of all inside wall surfaces.

The comparative lists of materials consumed in both models are depicted in the Table 1. Both Models have equal floor area and height (same indoor volume), so we can be compared the thermal behaviour of the both models. Because of the air cavity in the wall of Model II, their cross-sectional area is greater than that of the Model I that is depicted in Figure 1(a) and Figure 1(b).

For the same indoor volume, the material consumption in both models is almost the same, except the number of bricks used in their walls. It is because of the FAB size, which is more than that of the FCB size. The material thermal properties are depicted in Table 2.

The roof surface receives more heat flux than wall surface in a building throughout the day. Reinforced cement concrete (RCC) used for roof construction has high thermal conductivity. The outer temperature of conventional roofs varies from $32^{\circ} \mathrm{C}$ to $55^{\circ} \mathrm{C}$ in summer season in Allahabad. The green roof is essential to reduce incident solar radiation, because major heat transfer occurs through roof surface in building. If the roof surface receives solar heat gain, the indoor temperature also increases as the day progresses. A green roof is a green

Table 1. Material consumption of both models.

\begin{tabular}{cccc}
\hline \multirow{2}{*}{ Material } & Unit & \multicolumn{2}{c}{ Quantity } \\
\cline { 3 - 4 } & & Model I & Model II \\
\hline Bricks & Nos & $485($ FCB $)$ & 445 (FAB) \\
Cement & $\mathrm{kg}$ & 185 & 183 \\
Coarse sand (Badarpur) & cum & 0.191 & 0.185 \\
Fine sand (Jamuna sand) & cum & 0.245 & 0.225 \\
Aggregate & cum & 0.062 & 0.071 \\
Steel & $\mathrm{kg}$ & 14.2 & 15.8 \\
\hline
\end{tabular}

Table 2. Properties of building materials [19].

\begin{tabular}{cccc}
\hline Building Material & $\begin{array}{c}\text { Thermal } \\
\text { Conductivity } \mathrm{k}(\mathrm{W} / \mathrm{m} \cdot \mathrm{K})\end{array}$ & $\begin{array}{c}\text { Specific Heat } \\
\mathrm{C}_{\mathrm{p}}(\mathrm{J} / \mathrm{kg} \cdot \mathrm{K})\end{array}$ & Density $\left(\mathrm{kg} / \mathrm{m}^{3}\right)$ \\
\hline Fired clay brick (FCB) & 0.840 & 880 & 1820 \\
Fly ash brick (FAB) & 0.360 & 857 & 1700 \\
Cement Plaster & 0.721 & 840 & 1762 \\
$\begin{array}{c}\text { Reinforced } \\
\text { cement concrete (RCC) }\end{array}$ & $1.58[20]$ & 880 & 2288 \\
Air & $0.026[21]$ & 1005 & $1.12-1.2$ \\
Soil (wet) & $1.68[22]$ & $753-837$ & $1600-1800$ \\
Extruded polystyrene foam & $0.034-0.037$ & 1300 & $5-10$ \\
\hline
\end{tabular}


space created by adding layers of growing medium and plants on top of a traditional roofing system. The portable green roof image and cross-section view are shown in Figure 3(a) and Figure 3(b).

In this study, two small-scale building models have been constructed but they have different thermal properties and design characteristics. Both Model I \& II are operated in three different scenarios as follow:

\subsection{Scenarios}

For analyzing the effect of various aspects of green envelope on indoor temperature, three scenarios were examined. These are given below:

a) Model I and Model II both have conventional roof.

b) Model I with conventional roof and Model II with reflective coating on roof.

c) Model I with conventional roof and Model II with green roof.

1) Scenario 1

In first scenario, we have assessed the effect of wall material and wall design only in thermal comfort of built envelope. Model II made of fly ash brick with wall cavity, has been analyzed in comparison with the Model I, which is of conventional design and material as depicted in Figure 1(a) \& Figure 2(a).

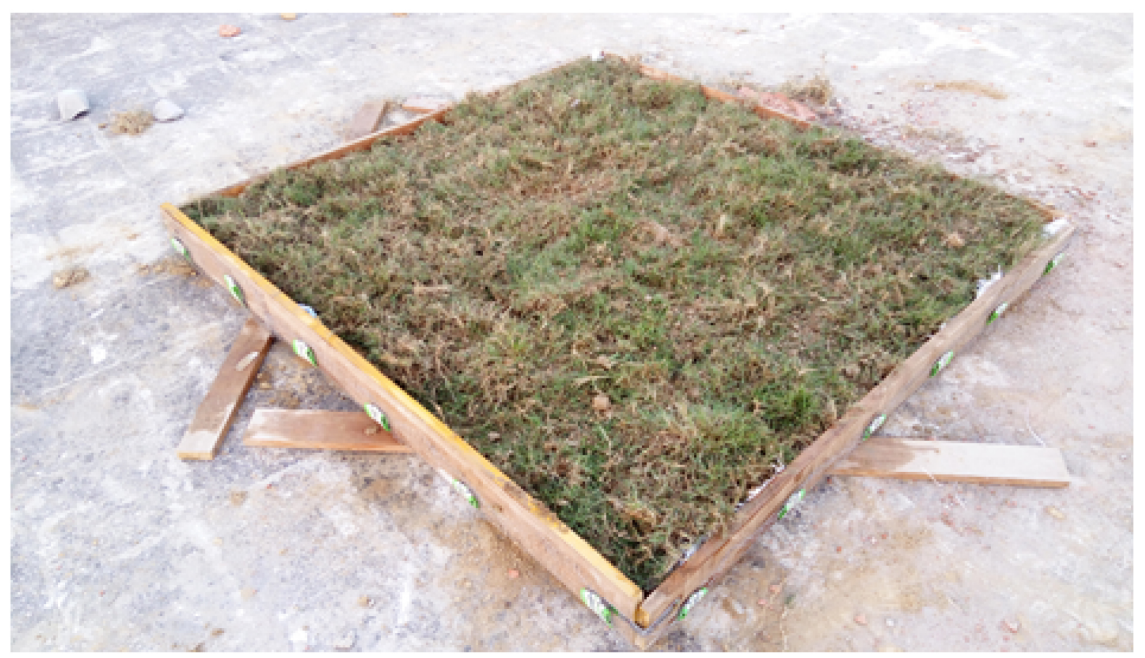

(a)

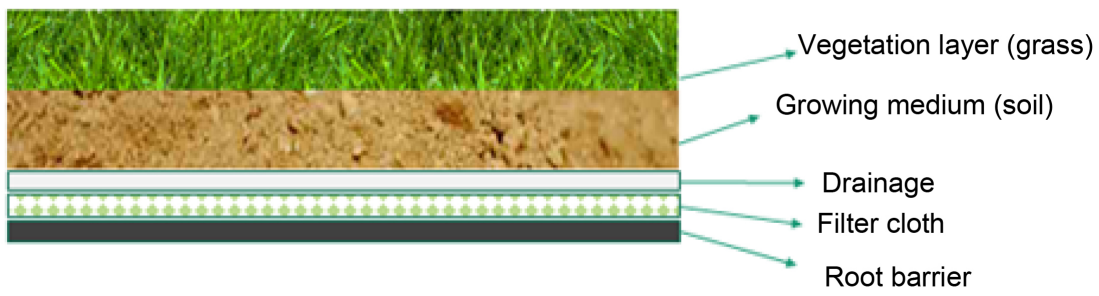

(b)

Figure 3. (a) Image of portable green roof; (b) Cross-sectional view of green roof. 


\section{2) Scenario 2}

In the second scenario, we have applied lime coating on the roof of Model II to see the albedo effect on the thermal behaviour of the built envelope. The temperature data was simultaneously obtained to analyze the thermal behaviour of both models. Picture of both models of second scenario condition are depicted in Figure 4.

\section{3) Scenario 3}

In the third scenario, we have put the portable green roof on the Model II and compared the thermal behaviour of Model II with Model I. This scenario helps us to provide comparative data for the analysis of the thermal behaviour of Model I \& Model II when the green roof feature is added into the Model II. Pictures of both models of third scenario condition are depicted in Figure 5.

\subsection{Sensible Heat Transfer (SHT) Load Evaluation}

For each scenario, outside \& inside surface temperature as well as indoor air temperatures of both building models were measured simultaneously. The SHT load of both models has been calculated and compared. The SHT load per unit area of envelope is evaluated as:

$$
Q / A=\Delta T / \sum R\left(\mathrm{~W} / \mathrm{m}^{2}\right)
$$

where,

$\Delta T$-Temperature difference of inside \& outside wall/roof surfaces $\left({ }^{\circ} \mathrm{C}\right.$ or $\left.\mathrm{K}\right)$,

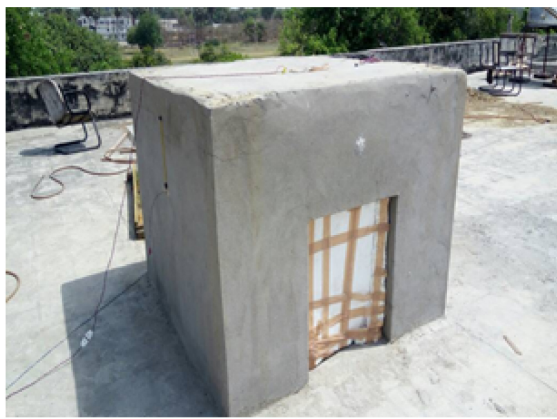

(a)

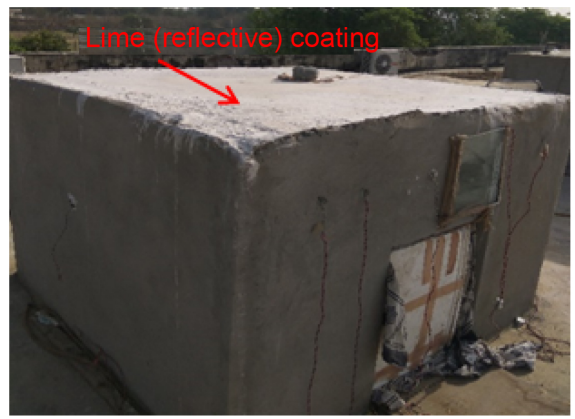

(b)

Figure 4. (a) Image of Model I; (b) Image of Model II.

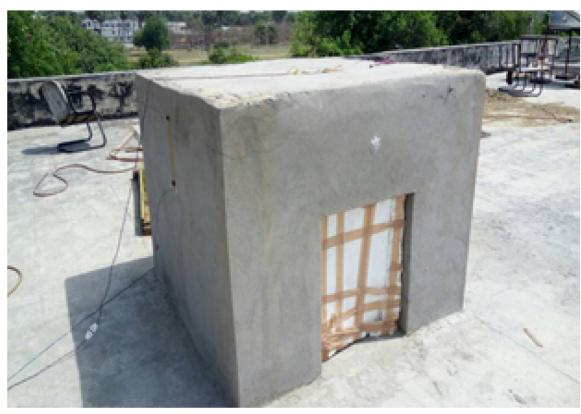

(a)

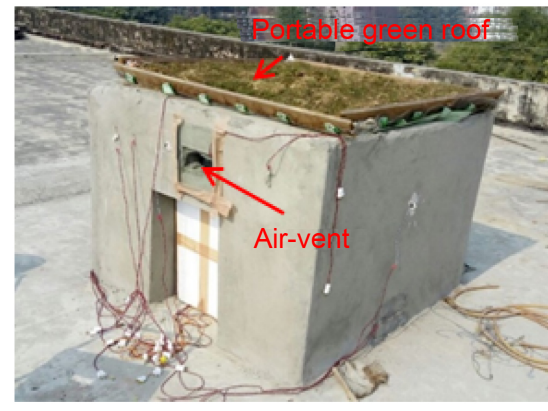

(b)

Figure 5. (a) Image of Model I; (b) Image of Model II. 
$\sum R$-Total thermal resistance of wall/roof $\left(\mathrm{m}^{2} \cdot \mathrm{K} / \mathrm{W}\right)$.

The monthly temperature data has been collected for all the three scenarios. The collected data has been utilized to calculate the heat transfer in both models through wall and roof. The total average SHT load per unit envelope area of the model has been calculated with the help of Equation (1):

$$
\left(Q_{\text {total }} / A_{\text {total }}\right)=\sum\left(Q_{\text {wall }} / A_{\text {wall }}\right)+Q_{\text {roof }} / A_{\text {roof }}\left(\mathrm{W} / \mathrm{m}^{2}\right)
$$

where,

$\sum\left(Q_{\text {wall }} / A_{\text {wall }}\right)=$ heat transfer through the walls of model per unit area of the wall;

$Q_{\text {roof }} / A_{\text {roof }}=$ heat transfer through the roof of the model per unit area of the roof.

With the help of Equation (1), we obtain SHT load per unit envelope area of Model II and Model I (base model) in each scenario. Reduction in total average SHT load per unit envelope area $\left(\Delta Q_{I} / A\right)$ of Model II with respect to Model I is calculated by Equation (2):

$$
\Delta Q_{r} / A=\left\{\sum\left(Q_{\text {total }} / A_{\text {total }}\right)_{\text {Model I }}-\sum\left(Q_{\text {total }} / A_{\text {total }}\right)_{\text {Model II }}\right\}\left(\mathrm{W} / \mathrm{m}^{2}\right)
$$

where;

$\left(Q_{\text {total }} / A_{\text {total }}\right)_{\text {Model I }}=$ Total average SHT load per unit envelope area of Model I; $\left(Q_{\text {total }} / A_{\text {total }}\right)_{\text {Model II }}=$ Total average SHT load per unit envelope area of Model II.

So the percentage reduction in total average SHT load per unit envelope area $\left(\% \Delta Q_{I} / A\right)$ can be calculated as,

$$
\%\left(\Delta Q_{r} / A\right)=\left[\left(\Delta Q_{r} / A\right) /\left\{\sum\left(Q_{\text {total }} / A_{\text {total }}\right)_{\text {Model I }}\right\}\right] \times 100
$$

Assumption:

- Unidirectional heat transfer takes place through wall and roof of the built envelope.

- Air is still \& uniformly dense in wall cavity of Model II for calculation of SHT load.

- Temperature of indoor air \& envelope surfaces are considered to be uniform.

\subsection{Electrical Energy \& GHG Reduction}

The reduction of SHT load caused by sustainable design is converted into electricity saving and for simplifying the calculation; it is assumed that HVAC system needs to maintain thermal comfort while operating at constant coefficient of performance (COP) of 3 .

Monthly electricity saving per unit envelope area $\left(E_{s}\right)$ for requirement of thermal comfort inside the built envelope is calculated by Equation (4):

$$
E_{\mathrm{s}}=\left\{\left(Q_{R} \times \text { No. of month's days }\right) / \text { COP of HVAC }\right\}\left(\mathrm{kWh}_{\mathrm{e}} / \mathrm{m}^{2}\right)
$$

where;

Daily average SHT load reduction $\left(Q_{R}\right)=\left\{\left(\Delta Q_{r} / A\right) \times 24\right.$ hours $\}\left(\mathrm{kWh}_{\mathrm{e}} / \mathrm{m}^{2}\right)$

Monthly GHG emission reduction per unit envelope area $\left(\mathrm{GHG}_{\mathrm{R}}\right)$ related to 
electricity saving is calculated by Equation (6):

$$
\mathrm{GHG}_{\mathrm{R}}=\left(E_{s}+\mathrm{T} \& \mathrm{D} \text { losses } \times E_{s}\right) \times \lambda_{e}\left(\mathrm{~kg} \mathrm{CO}_{2 \mathrm{eq}}\right)
$$

where;

Transmission \& Distribution (T\&D) losses of electrical grid in India $=23.04 \%$ [23]; Emission factor of electricity generation in India $\left(\lambda_{e}\right)=0.98 \mathrm{~kg} \mathrm{CO}_{2 \mathrm{eq}} / \mathrm{kWh}_{\mathrm{e}}$ [24].

\subsection{Climatic Condition}

The experimental models are constructed at Allahabad, India. Allahabad is a city in Uttar Pradesh with coordinates as $25^{\circ} 27^{\prime} \mathrm{N}$ and $81^{\circ} 51^{\prime} \mathrm{E}$. Allahabad has a humid subtropical climate common to cities in the plains of north India. The city has three seasons: summer (hot \& dry), winter (cool \& dry) and monsoon (hot \& humid). Warm weather lasts from March to September with peak temperatures up to $50^{\circ} \mathrm{C}$ in the hot $\&$ dry summer (from March to May) and up to $42^{\circ} \mathrm{C}$ in the hot \& humid monsoon season (from June to October). Winter runs from November to February with temperature rarely dropping to freezing point.

\section{Results}

The temperature data was collected during the period of February to May, 2017 (which is representative of a typical summer season in Allahabad, India), while taking into account the three possible scenarios. $\mathrm{K}$ type thermocouple (accuracy $\pm 1^{\circ} \mathrm{C}$ ) has been used to measure surface temperature as well as the indoor air temperature of the both models. The observation period of experiment was 8:00 am to 8:00 pm (i.e. 12 hours). Indoor temperature, sensible heat transfer load, electricity \& emission saving are obtained by comparing both models. The results obtained are as follows:

\subsection{Scenario 1}

In this scenario, we have collected data to assess the thermal behaviour of alternative design Model II and conventional design Model I. The experiment examines the thermal performance of alternative wall material (FAB) and passive feature (wall cavity of $5 \mathrm{~cm}$ ) on the built envelope with conventional building design. From the month of February to May, 2017, the average daily temperature profiles of indoor air of both models are shown in Figure 6. During the experiment, the average daily maximum indoor air temperature of Model I was $37.9^{\circ} \mathrm{C}$ while for Model II it was $35.4^{\circ} \mathrm{C}$ i.e. the difference between the indoor temperature is $2.5^{\circ} \mathrm{C}$ in the month of May, 2017. All internal surfaces of Model II during the experiment generally recorded lesser temperature than internal surface of Model I. It is because of high overall thermal resistance of wall of the Model II. Almost uniform temperature was observed for all inside wall surfaces for Model II.

Table 3 depicts the reduction in SHT load in Model II over Model I as calculated by Equation (2). The walls of Model II have higher overall thermal resistance 

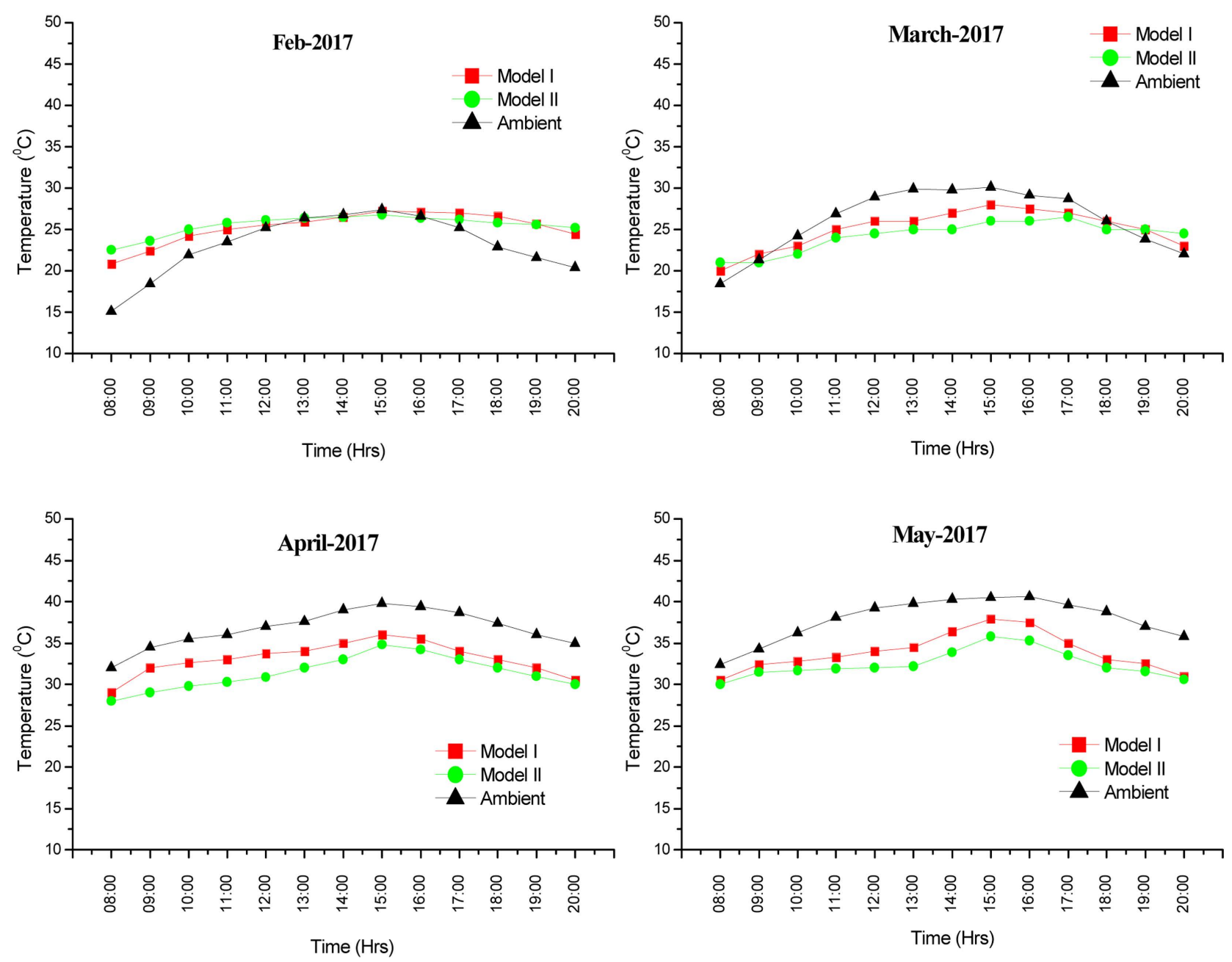

Figure 6. Daily average indoor air temperature profiles of both models for Scenario 1.

Table 3. Monthly average sensible heat transfer (SHT) load per unit envelope area.

\begin{tabular}{ccccc}
\hline Month & $\begin{array}{c}\text { Model I (Avg. SHT load per } \\
\text { unit envelope area })\left(\mathrm{W} / \mathrm{m}^{2}\right) \\
\left(Q_{\text {total }} / A_{\text {total }}\right)_{\text {Model I }}\end{array}$ & $\begin{array}{c}\text { Model II (Avg. SHT load } \\
\text { per unit envelope area }) \\
\left(\mathrm{W} / \mathrm{m}^{2}\right)\end{array}$ & $\begin{array}{c}\text { Avg. SHT load reduction } \\
\left(Q_{\text {total }} / A_{\text {total }}\right)_{\text {Model II }}\end{array}$ & $\begin{array}{c}\text { Percentage avg. SHT load } \\
\text { reduction per unit } \\
\text { envelope area }(\%)\end{array}$ \\
\hline Feb, 2017 & 13.27 & 10.50 & 2.77 & 20.9 \\
March, 2017 & 26.36 & 20.20 & 6.16 & 23.2 \\
April, 2017 & 28.95 & 22.84 & 6.11 & 21.1 \\
May, 2017 & 28.60 & 24.26 & 4.46 & 28.6 \\
\hline
\end{tabular}

than Model I because of the thermal properties of FAB \& air cavity, while the roof of both models has equal thermal resistance. The percentage reductions in average SHT load per unit envelope area of Model II over Model I is calculated by using Equation (3). It varies in between $21 \%$ - $29 \%$ for the same climatic condition. This percentage reduction is only for SHT load, and not in the overall air-conditioning load of the envelope.

Table 4 depicts the monthly electricity saving and related monthly GHG 
Table 4. Daily average SHT load per unit envelope area, Electricity saving \& Emission reduction.

\begin{tabular}{cccccc}
\hline Month & $\begin{array}{c}\text { Model I (SHT load } \\
\text { per unit envelope } \\
\text { area) }\left(\mathrm{kWh} / \mathrm{m}^{2}\right)\end{array}$ & $\begin{array}{c}\text { Model II (SHT } \\
\text { load per unit } \\
\text { envelope } \\
\text { area) }\left(\mathrm{kWh} / \mathrm{m}^{2}\right)\end{array}$ & $\begin{array}{c}\text { Reduction in SHT load } \\
\text { per unit envelope area } \\
\left(\mathrm{kWh} / \mathrm{m}^{2}\right)\end{array}$ & $\begin{array}{c}\text { Monthly electricity } \\
\text { saving } \\
\left(\mathrm{kWh} / \mathrm{m}^{2}\right)\end{array}$ & $\begin{array}{c}\text { Monthly GHG } \\
\text { emission reduction } \\
\left(\mathrm{kgCO} \mathrm{Ceq}_{2} / \mathrm{m}^{2}\right)\end{array}$ \\
\hline Feb, 2017 & 0.32 & 0.25 & 0.07 & 0.62 & 0.74 \\
March, 2017 & 0.64 & 0.48 & 0.16 & 1.50 & 1.5 \\
April, 2017 & 0.69 & 0.54 & 0.15 & 2.4 & 1.84 \\
May, 2017 & 0.81 & 0.58 & 0.23 & 2.90 \\
\hline
\end{tabular}

emission saving of unit envelope area of both models of Scenario 1 and calculated by using Equations (4) \& (5), respectively. From the analysis, we can say that only small changes in the wall of the built envelope can save monthly electricity up to $2.4 \mathrm{kWh}_{\mathrm{e}} / \mathrm{m}^{2}$, while GHG emissions are mitigated up to 2.9 $\mathrm{kgCO}_{2 \mathrm{eq}} / \mathrm{m}^{2}$.

\subsection{Scenario 2}

In this scenario, we try to assess the thermal behaviour of alternative design Model II consisting of reflective roof coating (lime coating) and conventional design Model I. We examined the thermal performance of alternative wall material (Fly ash brick) and passive features (wall cavity \& reflective roof coating) on the built envelope with conventional building design. Experiment duration for this scenario is same as all other scenarios, the temperature profiles of indoor air of both models are shown in Figure 7.

The maximum difference between the indoor temperatures of the two models is $3.2^{\circ} \mathrm{C}$ in the month of May, 2017. For the combined effect of wall and roof with reflective coating, the Daily \& Monthly average SHT load per unit envelope area $\left(Q_{\text {total }} / A_{\text {total }}\right)$ of both models are shown in Table $5 \&$ Table 6 , respectively.

\subsection{Scenario 3}

In this scenario, we experimentally assess the thermal behaviours of Model II (consisting of FAB cavity wall with portable green roof) with respect to Model I (based on conventional design). Experiment duration for this scenario is same as Scenario 1 . The average daily indoor air temperature profiles of both models are shown in Figure 8.

Maximum indoor air temperature recorded was $37.5^{\circ} \mathrm{C}$ for Model I and $31.3^{\circ} \mathrm{C}$ for Model II, while most of the time indoor air temperatures of Model II come in the range of thermal comfort. The maximum difference between the indoor temperatures of the two models is $6.2^{\circ} \mathrm{C}$ in the month of May, 2017. The roof receives maximum solar radiation as compared to walls throughout the day and influences the thermal comfort of the built envelope. The monthly average SHT load per unit envelope area $\left(Q_{\text {total }} / A_{\text {total }}\right)$ of both models are shown in Table 7. 

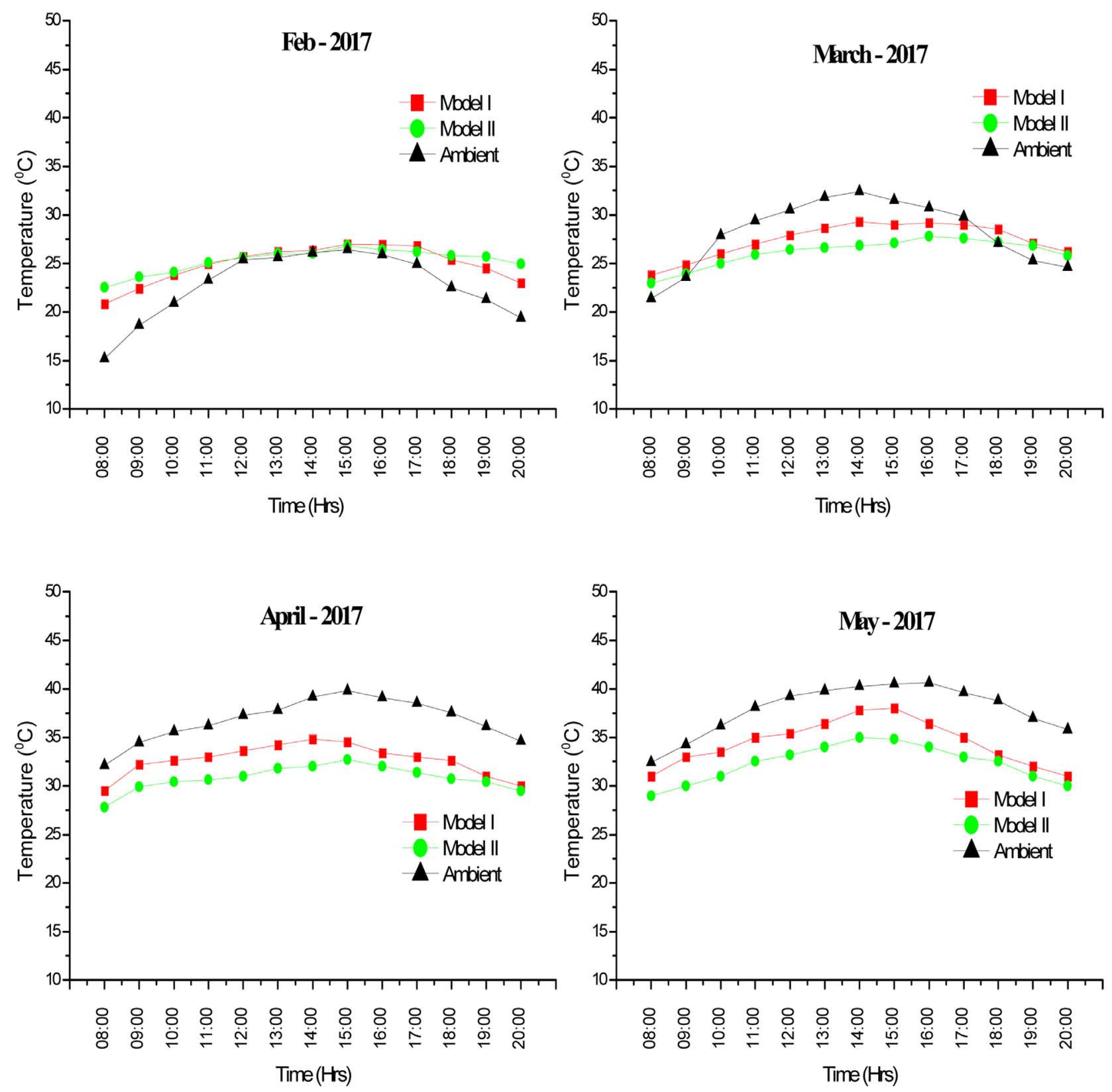

Figure 7. Daily average indoor air temperature profiles of both models for Scenario 2.

Green roof prevents the incident solar radiation to get transmitted inside, as this incident radiation is absorbed for the evaporation of moisture in the plants and soil. It decreases the heat transfer flow from the outside roof surface to the inside surface due to high thermal resistance of the roof that reduces overall heat gain of the built envelope. The percentage reduction in average SHT load per unit of the envelope area of Model II over Model I ranges between 64\% - 68\% for the same climatic condition. Experimental results show that green roof of the built envelope can save monthly electricity per unit envelope area up to 5.26 $\mathrm{kWh}_{\mathrm{e}} / \mathrm{m}^{2}$, while monthly GHG emissions reduction potential is up to 6.36 $\mathrm{kgCO}_{2 \mathrm{eq}} / \mathrm{m}^{2}$ as shown in Table 8. 

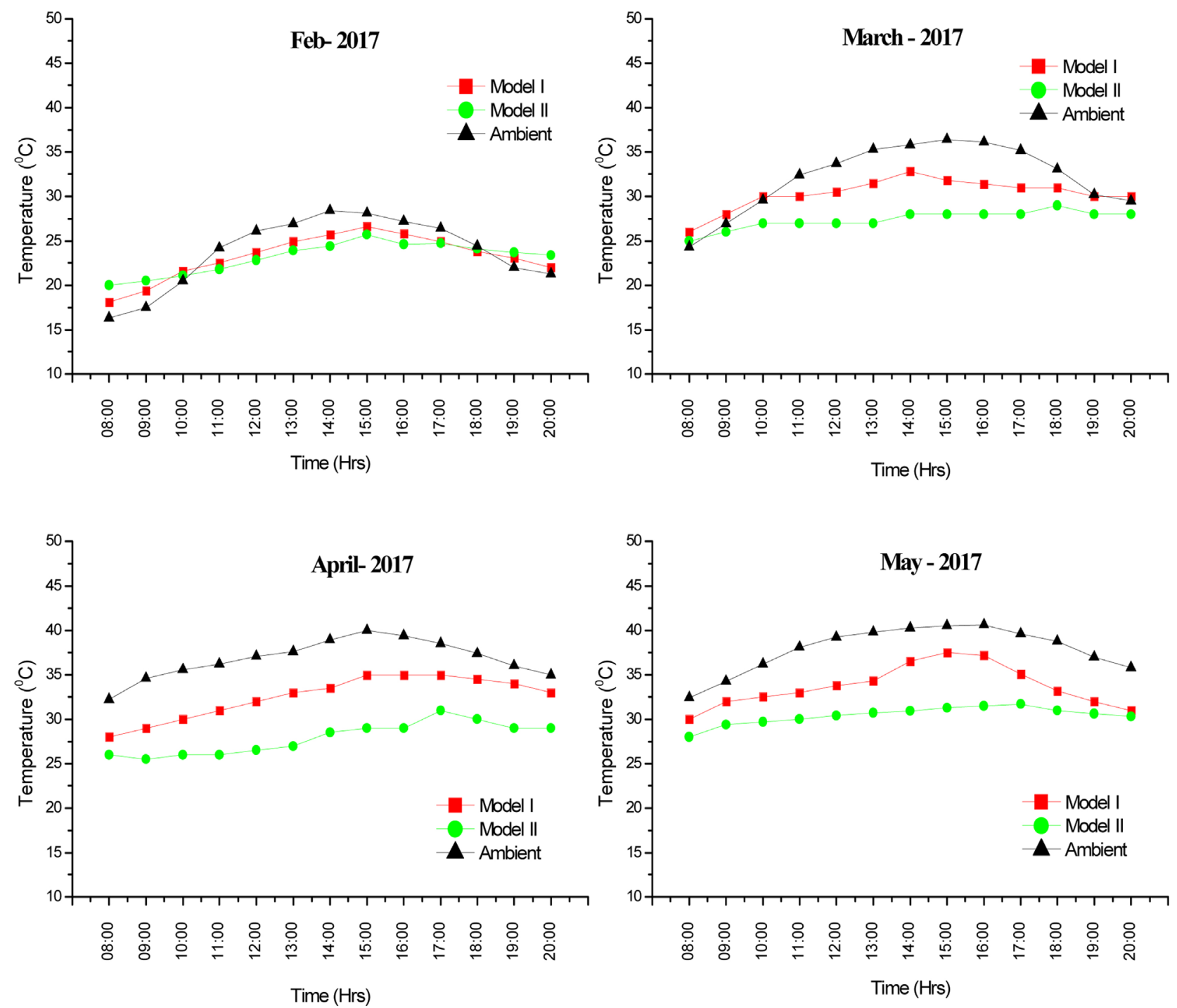

Figure 8. Daily average indoor air temperature profiles of both models for Scenario 3.

Table 5. Monthly average sensible heat transfer (SHT) load per unit envelope area.

\begin{tabular}{|c|c|c|c|c|}
\hline Month & $\begin{array}{l}\text { Avg. SHT load per unit } \\
\text { envelope area of Model I } \\
\left(\mathrm{W} / \mathrm{m}^{2}\right)\left(Q_{\text {total }} / A_{\text {total }}\right)_{\text {Model I }}\end{array}$ & $\begin{array}{l}\text { Avg. SHT load per unit } \\
\text { envelope area of Model II } \\
\left(\mathrm{W} / \mathrm{m}^{2}\right)\left(Q_{\text {total }} / A_{\text {total }}\right)_{\text {Model II }}\end{array}$ & $\begin{array}{l}\text { Avg. SHT load } \\
\text { reduction per unit } \\
\text { envelope area }\left(\mathrm{W} / \mathrm{m}^{2}\right)\end{array}$ & $\begin{array}{c}\text { Percentage avg. } \\
\text { SHT reduction per } \\
\text { unit envelope area } \\
(\%)\end{array}$ \\
\hline February, 2017 & 13.4 & 9.9 & 3.5 & $26.1 \%$ \\
\hline March, 2017 & 23.39 & 15.77 & 7.62 & $32.6 \%$ \\
\hline April, 2017 & 21.77 & 14.80 & 6.97 & $32 \%$ \\
\hline May, 2017 & 26.98 & 15.27 & 11.71 & $43.4 \%$ \\
\hline
\end{tabular}

\section{Conclusions}

The study investigated thermal performance of sustainable building design in Indian context for hot \& humid climatic condition. The avg. SHT load of all scenarios was measured and compared with each other. Model II (Scenario 3) 
Table 6. Daily average SHT load per unit envelope area, Electricity saving \& Emission reduction.

\begin{tabular}{cccccc}
\hline Month & $\begin{array}{c}\text { Model I (SHT load } \\
\text { per unit envelope } \\
\text { area) }\left(\mathrm{kWh} / \mathrm{m}^{2}\right)\end{array}$ & $\begin{array}{c}\text { Model II (SHT load } \\
\text { per unit envelope } \\
\text { area) }\left(\mathrm{kWh} / \mathrm{m}^{2}\right)\end{array}$ & $\begin{array}{c}\text { Reduction in SHT load } \\
\text { per unit envelope area } \\
\left(\mathrm{kWh} / \mathrm{m}^{2}\right)\end{array}$ & $\begin{array}{c}\text { Monthly electricity } \\
\text { saving }\left(\mathrm{kWh}_{\mathrm{e}} / \mathrm{m}^{2}\right)\end{array}$ & $\begin{array}{c}\text { Monthly GHG } \\
\text { emission reduction } \\
\left(\mathrm{kgCO} \mathrm{Ceq}^{2} / \mathrm{m}^{2}\right)\end{array}$ \\
\hline February, 2017 & 0.32 & 0.23 & 0.09 & 0.80 & 0.96 \\
March, 2017 & 0.56 & 0.37 & 0.19 & 1.88 & 2.28 \\
April, 2017 & 0.52 & 0.35 & 0.17 & 2.67 & 2.00 \\
May, 2017 & 0.64 & 0.36 & 0.28 & 2.92 & 3.52 \\
\hline
\end{tabular}

Table 7. Monthly average sensible heat transfer (SHT) load per unit envelope area.

\begin{tabular}{ccccc}
\hline Month & $\begin{array}{c}\text { Avg. SHT per unit envelope } \\
\text { area of Model I }\left(\mathrm{W} / \mathrm{m}^{2}\right) \\
\left(Q_{\text {total }} / A_{\text {total }}\right)_{\text {Model I }}\end{array}$ & $\begin{array}{c}\text { Avg. SHT load per unit } \\
\text { envelope area of Model II } \\
\left(\mathrm{W} / \mathrm{m}^{2}\right)\end{array}$ & $\begin{array}{c}\text { Avg. SHT load } \\
\text { reduction unit per }\end{array}$ & $\begin{array}{c}\text { Percentage avg. SHT } \\
\text { load reduction per unit } \\
\text { envelope area }(\%)\end{array}$ \\
\hline February, 2017 & 14.56 & 4.88 & 9.68 & $66.5 \%$ \\
envelope area $\left(\mathrm{W} / \mathrm{m}^{2}\right)$ & 14.73 & $63.9 \%$ \\
March, 2017 & 23.05 & 8.32 & 16.25 & $66.9 \%$ \\
April, 2017 & 24.30 & 8.05 & 21.21 & $67.4 \%$ \\
May, 2017 & 31.47 & 10.26 & \\
\hline
\end{tabular}

Table 8. Daily average sensible heat transfer (SHT) load, Electricity saving \& Emission reduction.

\begin{tabular}{cccccc}
\hline Month & $\begin{array}{c}\text { Model I (SHT load } \\
\text { per unit envelope } \\
\text { area) }\left(\mathrm{kWh} / \mathrm{m}^{2}\right)\end{array}$ & $\begin{array}{c}\text { Model II (SHT load } \\
\text { per unit envelope } \\
\text { area) }\left(\mathrm{kWh} / \mathrm{m}^{2}\right)\end{array}$ & $\begin{array}{c}\text { Reduction in SHT load } \\
\text { per unit envelope area } \\
\left(\mathrm{kWh} / \mathrm{m}^{2}\right)\end{array}$ & $\begin{array}{c}\text { Monthly } \\
\text { electricity saving } \\
\left(\mathrm{kWh} / \mathrm{m}^{2}\right)\end{array}$ & $\begin{array}{c}\text { Monthly GHG } \\
\text { emission } \\
\text { reduction } \\
\left(\mathrm{kgCO} \mathrm{Ceq}_{2} / \mathrm{m}^{2}\right)\end{array}$ \\
\hline February, 2017 & 0.35 & 0.11 & 0.24 & 2.17 & 2.62 \\
March, 2017 & 0.55 & 0.20 & 0.25 & 3.65 & 3.91 \\
April, 2017 & 0.58 & 0.19 & 0.39 & 5.40 & 4.70 \\
May, 2017 & 0.75 & 0.24 & 0.51 & 5.26 & 6.36 \\
\hline
\end{tabular}

that consists of green roof with alternative wall design provides SHT load reduction in the range of $64 \%-68 \%$ compared to conventional built envelope, Model II (Scenario 2) that consists of conventional roof (with reflective coating) and alternative wall design allows $26 \%$ - $44 \%$ less sensible heat transfer then conventional built envelope. Least difference in the sensible heat transfer is observed in Scenario 1 , it's because of only wall design change with respect to conventional built envelope.

The SHT load reduction has a direct influence on the electricity consumption of a building during operation phase. The monthly electricity saving range of 2.17 - $5.26 \mathrm{kWh}_{\mathrm{e}}$ per unit envelope area for Scenario 3 was highest among all scenarios, $0.8-2.92 \mathrm{kWh}_{\mathrm{e}}$ per unit envelope area for Scenario 2, and $0.62-2.4$ $\mathrm{kWh}_{\mathrm{e}}$ per unit envelope area saving was observed in Scenario 1 (lowest of all scenarios). Monthly GHG emission reduction based on electricity consumption of building follows the similar trend. For Scenario 3 it ranges between $2.62-6.32$ $\mathrm{kgCO}_{2 \mathrm{eq}} / \mathrm{m}^{2}$ per unit envelope area (highest among all scenarios), $0.96-3.52$ 
$\mathrm{kgCO}_{2 \mathrm{eq}} / \mathrm{m}^{2}$ per unit envelope area estimated for the Scenario 2, and $0.74-2.90$ $\mathrm{kgCO} 2 \mathrm{eq} / \mathrm{m}^{2}$ per unit envelope area estimated for the Scenario 1 (lowest in all scenarios).

According to experimental results, use of cavity wall (FAB) with green roofing method showed an effective solution for sustainable building design. The study may be extended to examine other green building features e.g. green wall, earth air tunnel, alternative reflective coating on roof etc.

\section{References}

[1] UNFCC: United Nations Framework Convention on Climate (2015). http://newsroom.unfccc.int/unfccc-newsroom/finale-cop21/

[2] Alnaser, N.W., Flanagan, R. and Alnaser, W.E. (2008) Model for Calculating the Sustainable Building Index (SBI) in the Kingdom of Bahrain. Energy and Buildings, 40, 2037-2043. https://doi.org/10.1016/j.enbuild.2008.05.015

[3] Asif, M., Muneer, T. and Kelley, R. (2007) Life Cycle Assessment: A Case Study of a Dwelling Home in Scotland. Building Environment, 42, 1391-1394. https://doi.org/10.1016/j.buildenv.2005.11.023

[4] Zabalza Bribián, I., Aranda Usón, A. and Scarpellini, S. (2009) Life Cycle Assessment in Buildings: State-of-the-Art and Simplified LCA Methodology as a Complement for Building Certification. Building Environment, 44, 2510-2520. https://doi.org/10.1016/j.buildenv.2009.05.001

[5] Ramesh, T., Prakash, R. and Shukla, K.K. (2010) Life Cycle Analysis of Buildings: An Overview. Energy and Buildings, 42, 1592-1600. https://doi.org/10.1016/j.enbuild.2010.05.007

[6] Ramesh, T., Prakash, R. and Shukla, K.K. (2012) Life Cycle Approach in Evaluating Energy Performance of Residential Buildings in Indian Context. Energy and Building, 54, 259-265. https://doi.org/10.1016/j.enbuild.2012.07.016

[7] Air Conditioning Policy and Guidance on Thermal Comfort (2013) University of Lancashire.

http://www.uclan.ac.uk/safety_health_environment/assets/FM_SHE_031_Air_Cond itioning_Policy_and_Guidance_on_Thermal_Comfort.docx

[8] Mingotti, N., Chenvidyakarn, T. and Woods, A.W. (2011) The Fluid Mechanics of Then Natural Ventilation of a Narrow-Cavity Double-Skin Façade. Building Environment, 46, 807-823. https://doi.org/10.1016/j.buildenv.2010.09.015

[9] Fly Ash Brick Information (2014). http://flyashbricksinfo.com/fly-ash-brick-vs-normal-clay-bricks.html

[10] Vandana, R.K., Balwinder, P.L. and Deepankar, K.A. (2014) Study of Properties of Light Weight Fly Ash Brick. International Journal of Engineering Research and Applications, 49-53.

[11] Kumar, A. and Suman, B.M. (2013) Experimental Evaluation of Insulation Materials for Walls and Roofs and Their Impact on Indoor Thermal Comfort under Composite Climate. Building and Environment, 59, 635-643.

[12] Hall, M. (2011) Materials for Energy Efficiency and Thermal Comfort in Buildings. University of Nottingham.

[13] Cheng, V., Nag, E. and Givoni, B. (2005) Effect of Envelope Colour and Thermal Mass on Indoor Temperatures in Hot Humid Climate. Solar Energy, 78, 528-534.

[14] Romagnoni, P. and Peron, F. (2008) Impact of Solar Radiation on the Temperature 
of Thermal Insulation Materials in Roof Applications. Architecture University Institute of Venice.

[15] Jayasinghe, M.T.R., Attalage, R.A. and Jayawardena, A.I. (2003) Roof Orientation, Roofing Materials and Roof Surface Colour: Their Influence on Indoor Thermal Comfort in Warm Humid Climates. Energy for Sustainable Development, 7, 16-27.

[16] Akridge, J.M. (1998) High-Albedo Roof Coating-Impact on Energy Consumption. ASHRAE Transactions, 104, 957-962.

[17] Jaffal, I., Ouldboukhitine, S. and Belarbi, R. (2012) A Comprehensive Study of the Impact of Green Roofs on Building Energy Performance. Renewable Energy, 43, 157-164.

[18] National Building Code of India (NBC) (2016). http://www.bis.org.in/sf/nbc.htm

[19] Ramesh, T., Prakash, R. and Shukla, K.K. (2012) Life Cycle Energy Analysis of a Residential Building with Different Envelopes and Climates in Indian Context. Applied Energy, 89, 193-202.

[20] Nayak, J.K. and Prajapati, J.A. (2006) Handbook on Energy Conscious Buildings. http://www.mnre.gov.in/solar-energy/startpage.pdf

[21] Koeinigsberger, O.H., Ingersoll, T.G., Mayhew, A. and Szokolay, S.V. (1974) Manual of Tropical Housing and Building Climate Design. Universityies Press.

[22] Permpituck, S. and Namprakai, P. (2012) The Energy Consumption Performance of Roof Lawn Gardens in Thailand. Renewable Energy, 40, 98-103.

[23] National Statistical Organisation Ministry of Statistics and Programme Implementation Government of India. http://www.mospi.gov.in

[24] Bhawan, S. and Puram, R.K. (2014) $\mathrm{CO}_{2}$ Baseline Database for the Indian Power Sector, Version 10. Government of India, Ministry of Power, Central Electricity Authority.

http://cea.nic.in/reports/others/thermal/tpece/cdm_co2/user_guide_ver10.pdf

\section{Submit or recommend next manuscript to SCIRP and we will provide best service for you:}

Accepting pre-submission inquiries through Email, Facebook, LinkedIn, Twitter, etc. A wide selection of journals (inclusive of 9 subjects, more than 200 journals) Providing 24-hour high-quality service User-friendly online submission system Fair and swift peer-review system Efficient typesetting and proofreading procedure Display of the result of downloads and visits, as well as the number of cited articles Maximum dissemination of your research work

Submit your manuscript at: http://papersubmission.scirp.org/ Or contact ojee@scirp.org 